Int. J. Med. Surg. Sci.,

2(3):551-555, 2015.

\title{
Using Piezoelectric System in Oral and Maxillofacial Surgery
}

\section{Uso del Sistema Piezoeléctrico en Cirugía Oral y Maxilofacial}

\author{
Eduardo Thomé de Azevedo*; Davani Latarullo Costa**; \\ Paulo Eduardo Przysiezny** \& Leandro Eduardo Kluppel**
}

De AZeVedo, E. T.; COSTA, D. L.; PRZYSiezNY, P. E. \& KLUPPEL, L. E. Using piezoelectric system in oral and maxillofacial surgery. Int. J. Med. Surg. Sci., 2(3):551-555, 2015.

SUMMARY: Motors and handpieces with the piezoelectric system have recently been used in several surgeries, following the current minimally invasive trend surgery. The system consists of crystals or ceramics undergoing deformation when exposed to electrical current, resulting in an oscillating movement with ultrasound frequency. In the Oral and Maxillofacial Surgery field activity, the piezosurgery may be used in maxillary and mandibular osteotomies in the orthognathic surgery, alveolar corticotomies, cysts tumors, facial trauma surgery, among others. This study aims to present a literary review on the piezoelectric system, which allows discussion to their use and effectiveness in oral surgery procedures.

KEY WORDS: Oral Surgery; Orthognathic Surgery; Osteotomy; Piezosurgery.

\section{INTRODUCTION}

The piezoelectric technology has been purposed for the first time in 1880 by Jean and Marie Curie, referring to crystals which generate electric flow under mechanic pressure. Its reciprocate action was further found out, ensuring therefore a cutting effect to the piezoelectric system. The process consists of crystals or ceramics which get deformations when exposed to electric flows, resulting in an oscillating movement with ultrasound frequency that has the power to precisely cut bone structures without causing injuries in the soft tissues. This article has as its as to look over its effectiveness and efficiency in oral surgery procedures (Landes et al., 2008; Agarwal et al., 2014).

\section{LITERATURE REVIEW}

Motors and handpieces with the piezoelectric system have been used recently in several kinds of surgeries, following the current minimally invasive trend surgery (Landes et al. 2008). The technology works when micro crystals and ceramics get an electric flow action, expanding its polarity and making up perpendicular contractions when exposed to the flows. The result of these physical phenomena are 26 to 38 thousand oscillating micro movements (ultrasound) with high power of cut, accurate precision, little toil and a huge efficiency (Yaman \& Suer, 2013) (Fig. 1A/B).

This method has recently been created with the aim of performing osteotomies more precisely, with minimum adverse damages to the soft tissues, minor potential of associated bone necrosis (Labanca et al., 2008; Vercelloti et al., 2001). In addition there is a linked flood system which ensures the work and comfort of the professionals during the surgery performance, besides promoting a continuous prevention to the intra bone temperature increase. The

* Fellow program in Oral and Maxillofacial Surgery at the ILAPEO, Curitiba/PR, Brazil.

** Professor in Oral and Maxillofacial Surgeyr at the ILAPEO, Curitiba/PR, Brazil.

ILAPEO - Latin-American Institute of Research and Education of Dentistry. 
visibility of the operation field is always maximum due to the "Cavitation Effect" - Physical Effect resulting from Ultrasound vibration with water - air bubbles"; provided by the water or liquid used in the cooling of high frequency during a stage of work, dwindling the blood influx in the cut area (Fig. 2) (Eggers et al., 2004; Landes et al.).

One of the main advantages of using the piezosurgery is its minor intra bone temperature when compared to other cut systems, thus, the osteotomies are performed with more precision, agility, simultaneously preventing complication. The precision of osteotomies also depend on the proper use of the handpieces points (Harder et al., 2009). Therefore, some important positive aspects must be highlighted considering the use of piezoelectric system in oral surgeries: safety, precision, comfort to the professional and to the patient, visibility of operatory field, temperature control and blander post operative period (Landes et al.; Louise \& Macia, 2009; Vercelloti et al.). Consequently, its use in Odontology is wide, passing by several specialties.

In Oral Surgery, the piezosurgery may act preventing injuries to the inferior alveolar nerve in inferior third molar surgeries which present any degree of sensitive morbidity. Also, it may be used to perform the inferior alveolar nerve lateralization technique
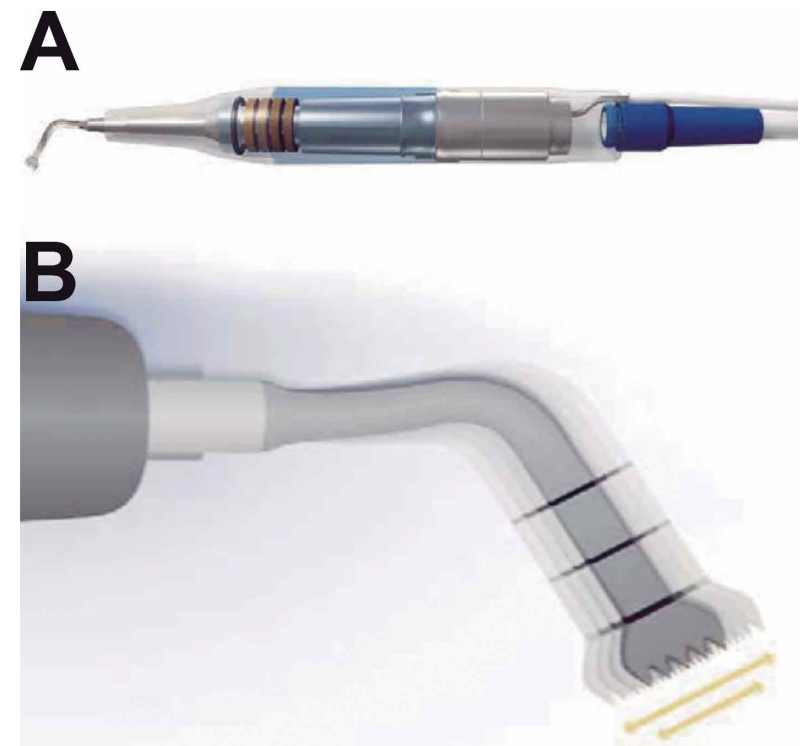

Fig. 1. A) Piezoeletric handpiece system. B) Physical phenomena are 26 to 38 thousand oscillating micro movements.

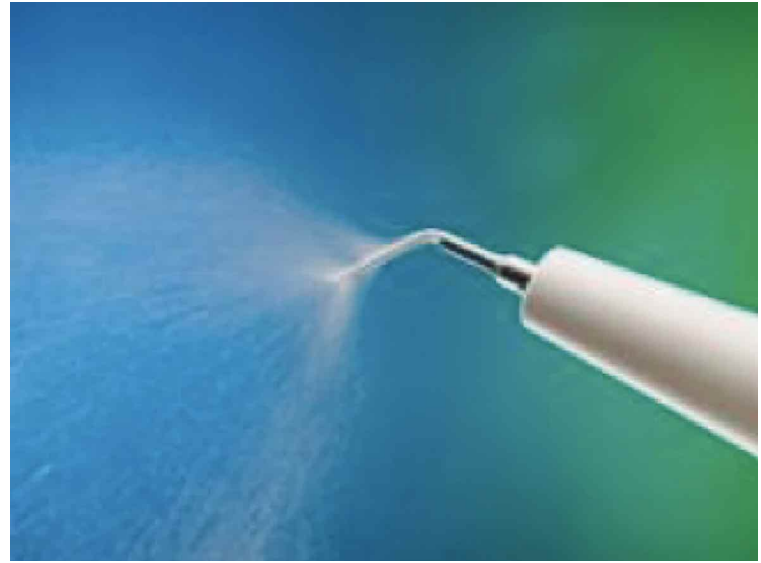

Fig. 2. "Cavitation Effect" - Physical Effect resulting from Ultrasound vibration with water -

preventing injuries to the nerve at osteotomy time (Fig. 3). Non-traumatic extractions, removing ankylosed teeth, cystic injuries and tumors also can be performed with the piezoelectric system and its specific tips (Landes et al.; Louise \& Macia, 2009; Rulla et al., 2013).

Another surgery procedure that might be performed with this system is the bone grafting, of which we may highlight the lifting of the maxillary sinus. This surgery is widely used as a preparation for performing maxillary

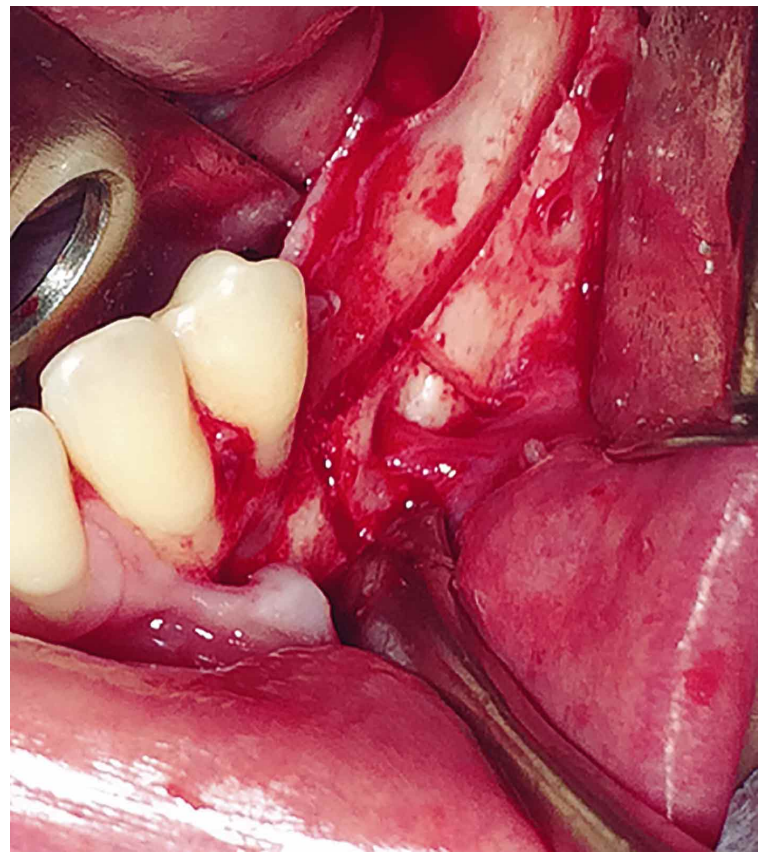

Fig. 3. Inferior alveolar nerve lateralization. 

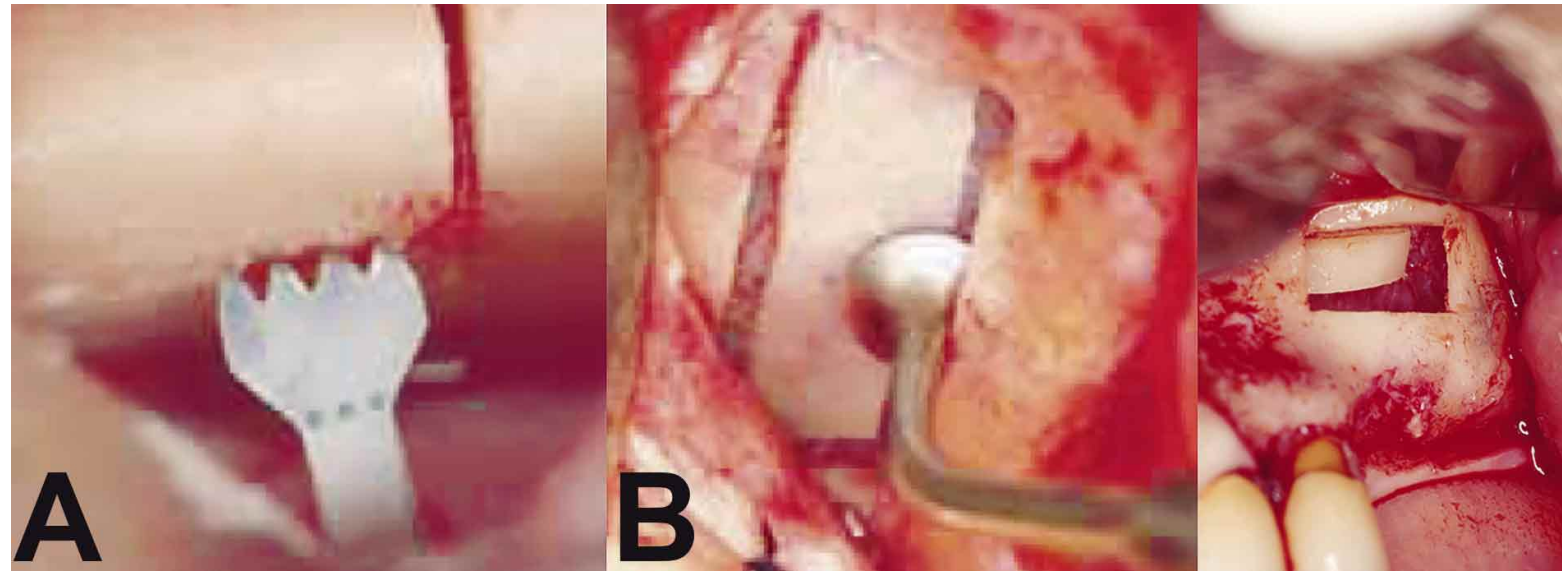

Fig. 4. A) Bone grafting by Piezoeletric.

B) Sinus Lifting by Piezoeletric.

implants, however the traditional surgery has a rate from $11 \%$ to $56 \%$ of perforation of the maxillary sinus membrane -Schneider Membrane - without taking into account the hemorrhagic and neuron sensitive complications. The piezosurgery, due to its characteristics of soft tissue preservation, guarantee a preparation of the maxillary borders with no injury of the membrane during the osteotomies, making it an effective way to perform the maxillary sinus lifting without further complications (Louise \& Macia; Toscano et al., 2010) (Fig. 4A/B).

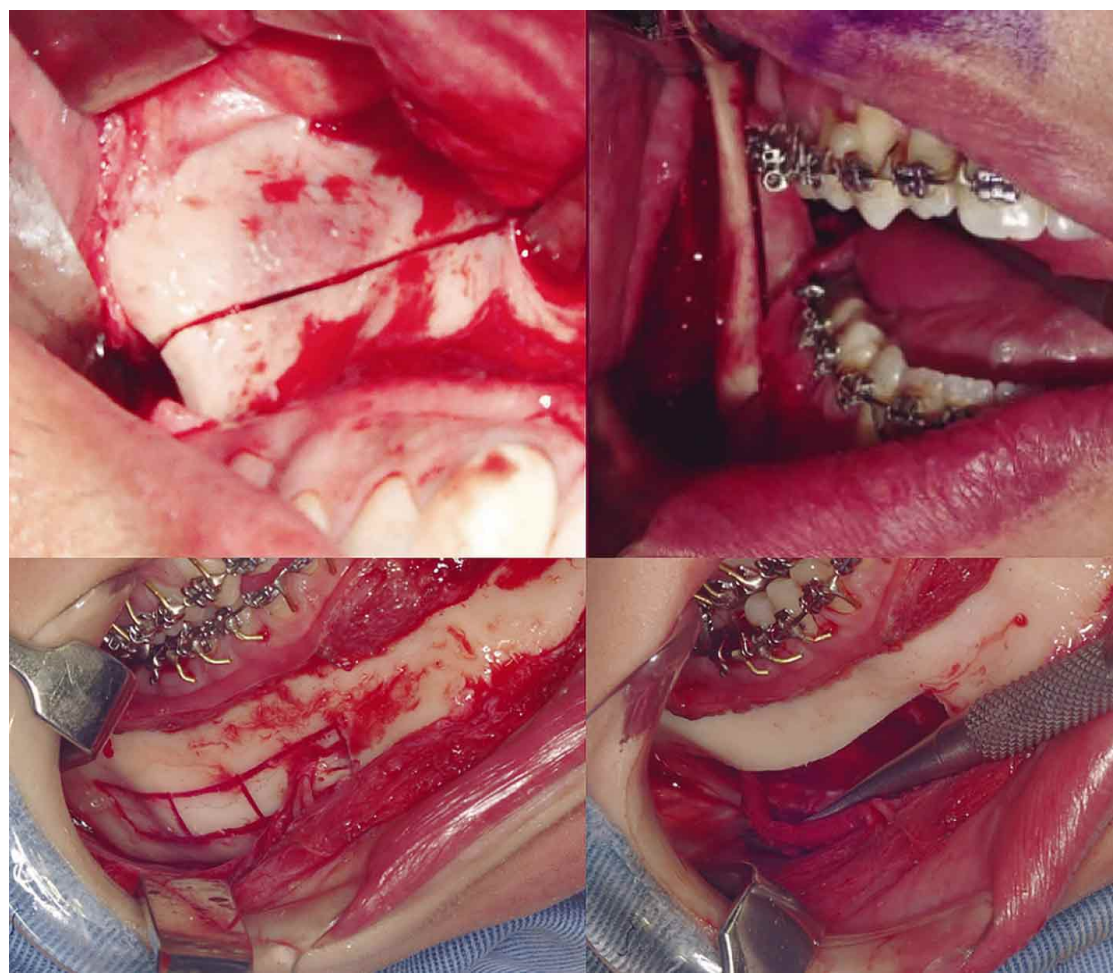

Fig. 5. Osteotomies Le Fort I / Sagital split osteotomy and Subapical total osteotomy performing by piezosurgery.
In addition, it may be used as an alveolar preparation for dental implants. Recently, a study by Preti et al. (2007), comparing the osseous integration and neoformation in perforated implant sites with piezoelectric system instead of conventional drills; proving to be an effective technique. An increase of the osteoblast quantity was observed when comparing to the perforations with drills, as well as minor post operatory effects and visible bone remodeling, within 56 days. In parendodontic and periodontal surgeries, it provides a cleaner visual field of the surgery site (Labanca et al.).

For the Bucomaxillofacial surgery branch, the piezosurgery may be used in maxillary and mandibular osteotomies in orthognathic surgeries, as well as in alveolar corticotomies, cysts and tumors, surgeries of facial traumas, osteogenic distractions and procedures of pre-implant insertion (Fig. 5) (Agarwal et al.; Eggers et al.; Landes etal.; Labanca et al.; Robiony et al., 2004).

In multiple maxillary osteotomies, it has shown itself effective with minimum risk of bleeding and bone necroses (Vercelloti et a/.). These osteotomies are too close to 
delicate structures like nerves, blood vessels and dental structures and the use of rotating systems like drills or macro-oscillatory systems like saws tend to cause a larger increase in the intra bone temperature, breaking of capillaries and border necrosis; besides having a larger chance of injuries on the noble structures around the areas of osteotomy. The piezosurgery performs a selective recognition of both hard and mineralized tissues and it limits its cut for each type. For this reason it is highly recommended in osteotomies which are very close to the dental and soft tissues, mainly nerves; it has demonstrated itself as an extremely efficient method to perform orthognathic surgeries (Agarwal et al.; Landes et al.; Preti et al.).

\section{DISCUSSION}

The piezoelectric technology has featured a selective cut of mineralized tissues and preservation of soft tissues when compared to traditional methods with drills and saws (Labanca et al.; Landes et al.). It has been effective on the intra bone temperature control during the osteotomies in oral surgeries. It also counts on an irrigating system coped with the handpiece, preventing border bone necroses to the borders of the osteotomy besides avoiding periodontal injuries on the tissues (Eggers et al.; Labanca et al.; Louise \& Macia). It has a highly precise cut, with a low rate of bleeding during the osteotomy, however there must be focus on the quality and indication of the specific points in each kind of cut (Harder et al.; Labanca et al.).

In oral surgeries, it is recommended in procedures which need special caution with the noble and adjacent structures to be preserved, such as Schneider membrane in surgeries of maxillary sinus lifting and osteotomies which have very close vessels and nerves as well as in surgeries of inferior alveolar nerve lateralization. In addition, the piezosurgery is indicated to remove inner third molars, nontraumatic extraction of pre-implanted teeth or ankylosed teeth, cystic and tumor maxillary and mandibular resection, facial surgeries, alveolar corticotomies for orthodontic reasons - due to its capability of preserving the periodontal tissues - osteotomies for osteogenic distraction, bone grafting, periodontal and parendodontic surgeries and maxillary-mandibular osteotomies, segmented or not, when performing Orthognathic surgeries (Agarwal et al.; Eggers et al.; Labanca et al.; Landes et al.; Robiony et al.; Toscano et al.).

There are no absolute contraindications, but one such is electrical peacemakers, in either the patient or the operator, which is a contraindication. Also, sometimes the age factor should be a relative contraindication for any surgery (Agarwal et al.).

The action of piezosurgery device can be summarized by the following points: its precise bone cutting with soft tissue preservation, asepsis surgery, effect of cavitation which allows the maximum intra operative visibility and high predictability and minimum of bone stress with excellent tissue healing. Also, a great time of postoperative is observed at the patients with less edema (Preti et al.; Vercelloti et al.).

Also, Agarwal et al. and Yaman \& Suer reveals that the piezosurgery increased the concentration of BMP (bone morphogenic protein) and decrease some of the inflammatory citokines in the bone. This technique should be applied in pediatric or adult patients and it is fantastic for precision, predictability and treatment outcomes of any surgical procedure.

\section{CONCLUSION}

According to the studies and authors reviewed in this article, it is possible to conclude that the use of piezoelectric technology to perform several procedures in oral surgeries can guarantee principles like safety, precision, selective bone cutting, comfort both for the professional and the patient, and a blander post operatory with fewer sores. The success rate in surgeries is high, as well as the prevention average of post operatory complications, without the increase of the trans-operatory surgery time; being highly recommended for the performance of oral surgeries lately. 
DE AZeVedo, E. T.; COSTA, D. L.; PRZYSIEZNY, P. E. \& KLUPPEL, L. E. Using piezoelectric system in oral and maxillofacial surgery. Int. J. Med. Surg. Sci., 2(3):551-555, 2015.

DE AZEVEDO, E. T.; COSTA, D. L.; PRZYSIEZNY, P. E. \& KLUPPEL, L. E. Uso del sistema piezoeléctrico en cirugía oral y maxilofacial. Int. J. Med. Surg. Sci., 2(3):551-555, 2015.

RESUMEN: Motores y piezas de mano con sistema piezoeléctrico han sido recientemente utilizados en algunos tipos de cirugías, siguiendo la tendencia actual de cirugía mínimamente invasiva. El sistema consiste de cristales o cerámicos bajo deformación cuando son expuestas a corriente eléctrica, resultando en un movimiento oscilatorio con frecuencia ultrasónica. En el campo de la cirugía oral y maxilofacial, el sistema piezoeléctrico puede ser utilizado en osteotomías maxilares o mandibulares como en cirugía ortognática, corticotomias alveolares, quistes, tumores, cirugía de trauma facial, y otras. El presente estudio tiene el objetivo realizar una revisión de la literatura sobre sistemas piezoeléctricos, lo que permite discutir su aplicación y uso en procedimientos de cirugía oral.

PALABRAS CLAVE: Cirugía oral; Cirugía ortognatica; Osteotomías; Piezocirugía.

\section{REFERENCES}

Agarwal, E.; Masamatti, S. S. \& Kumar, A. Escalating role of piezosurgery in dental therapeutics. J. Clin. Diagn. Res., 8(10):ZE08-11, 2014.

Eggers, G.; Klein, J.; Blank, J. \& Hassfeld, S. Piezosurgery: an ultrasound device for cutting bone and its use and limitations in maxillofacial surgery. Br. J. Oral Maxillofac. Surg., 42(5):4513, 2004.

Harder, S.; Wolfart, S.; Mehl, C. \& Kern, M. Performance of ultrasonic devices for bone surgery and associated intraosseous temperature development. Int. J. Oral Maxillofac. Implants, 24(3):484-90, 2009.

Labanca, M.; Azzola, F.; Vinci, R. \& Rodella, L. F. Piezoelectric surgery: twenty years of use. Br. J. Oral Maxillofac. Surg., 46(4):265-9, 2008.

Landes, C. A.; Stübinger, S.; Rieger, J.; Williger, B.; Ha, T. K. \& Sader, R. Critical evaluation of piezoelectric osteotomy in orthognathic surgery: operative technique, blood loss, time requirement, nerve and vessel integrity. J. Oral Maxillofac. Surg., 66(4):657-74, 2008.

Louise, F. \& Macia, Y. Can piezoelectric surgery change daily dental practice? Australas. Dent. Pract., 3:140-4, 2009

Preti, G.; Martinasso, G.; Peirone, B.; Navone, R.; Manzella, C. ; Muzio, G. ; Russo, C. ; Canuto, R. A. \& Schierano, G. Cytokines and growth factors involved in the osseointegration of oral titanium implants positioned using piezoelectric bone surgery versus a drill technique: a pilot study in minipigs. J. Periodontol., 78(4):716-22, 2007.

Robiony, M.; Polini, F.; Costa, F.; Vercellotti, T. \& Politi,
M. Piezoelectric bone cutting in multipiece maxillary osteotomies. J. Oral Maxillofac. Surg., 62(6):759-61, 2004.

Rulla, R.; Addabbo, F.; Papaccio, G.; D'Aquino, R. \& Festa, V. M. Piezoelectric device vs. conventional rotative instruments in impacted third molar surgery: relationships between surgical difficulty and postoperative pain with histological evaluations. J. Craniomaxillofac. Surg., 41(2):e33-8, 2013.

Toscano, N. J.; Holtzclaw, D. \& Rosen, P. S. The effect of piezoelectric use on open sinus lift perforation: a retrospective evaluation of 56 consecutively treated cases from private practices. $J$. Periodontol., 81(1):167-71, 2010.

Vercelloti, T.; Crocave, A.; Palermo, A. \& Molfetta, A. The piezoelectric osteotomy in orthopedics: Clinical and histological evaluations (Pilot study in animals). Mediterr. J. Surg. Med., 9:89-96, 2001.

Yaman, Z. \& Suer, B. T. Piezoelectric surgery in oral and maxillofacial surgery. Ann. Oral Maxillofac. Surg., 1(1):5, 2013.

Correspondence to:

Davani Latarullo Costa

Professor in Oral and Maxillofacial Surgeyr

ILAPEO - Latin-American Institute of Research and Education of Dentistry.

Curitiba/Pr

BRAZIL

Email: costabuco@yahoo.com.br

Received: 22-07-2015

Accepted: 24-08-2015 